Article

\title{
Synthesis of $\mathrm{MFe}_{2} \mathrm{O}_{4} / \mathrm{CNS}(\mathrm{M}=\mathrm{Zn}, \mathrm{Ni}, \mathrm{Mn})$ Composites Derived from Rice Husk by the Hydrothermal-Microwave Method for Remediation of Paddy Fields
}

\author{
Tutik Setianingsih $^{1}$, ${ }^{\text {, Bambang Susilo }}{ }^{2}$, Siti Mutrofin ${ }^{1}$, Bambang Ismuyanto ${ }^{3}$, Andreas Novan Endaryana ${ }^{1}$ \\ and Yoandra Nadya Yoniansyah ${ }^{1}$ \\ 1 Department of Chemistry, Brawajaya University, Malang 65145, Jawa Timur, Indonesia; \\ mutrofin@ub.ac.id (S.M.); andreasnovane1@gmail.com (A.N.E.); \\ yoandranadyayoniansyah@gmail.com (Y.N.Y.) \\ 2 Department of Agricultural Engineering, Brawajaya University, Malang 65145, Jawa Timur, Indonesia; \\ susilo@ub.ac.id \\ 3 Department of Chemical Engineering, Brawajaya University, Malang 65145, Jawa Timur, Indonesia; \\ bambangismu@ub.ac.id \\ * Correspondence: tutiksetia@ub.ac.id; Tel.: +62-0341-575838
}

check for updates

Citation: Setianingsih, T.; Susilo, B.; Mutrofin, S.; Ismuyanto, B.; Endaryana, A.N.; Yoniansyah, Y.N. Synthesis of $\mathrm{MFe}_{2} \mathrm{O}_{4} / \mathrm{CNS}(\mathrm{M}=\mathrm{Zn}$, $\mathrm{Ni}, \mathrm{Mn}$ ) Composites Derived from Rice Husk by the

Hydrothermal-Microwave Method for Remediation of Paddy Fields. Processes 2021, 9, 1349. https:// doi.org/10.3390/pr9081349

Academic Editors: David W. Mazyck, Amy Borello Gruss and Emily K. Faulconer

Received: 22 June 2021

Accepted: 26 July 2021

Published: 30 July 2021

Publisher's Note: MDPI stays neutral with regard to jurisdictional claims in published maps and institutional affiliations.

Copyright: (c) 2021 by the authors. Licensee MDPI, Basel, Switzerland. This article is an open access article distributed under the terms and conditions of the Creative Commons Attribution (CC BY) license (https:// creativecommons.org/licenses/by/ $4.0 /)$.

\begin{abstract}
In this research work, $\mathrm{MFe}_{2} \mathrm{O}_{4} / \mathrm{CNS}$ was prepared using the hydrothermal-microwave method. The influence of cations $(\mathrm{M})$ toward functional groups of composites and their performance in pesticide degradation were studied. Rice husk was pyrolyzed hydrothermally $\left(200{ }^{\circ} \mathrm{C}, 6 \mathrm{~h}\right)$ and by microwave ( $800 \mathrm{~W}, 40 \mathrm{~min}$ ). Each product was mixed with $\mathrm{MCl}_{2}(\mathrm{Zn}, \mathrm{Ni}, \mathrm{Mn}), \mathrm{FeCl}_{3}, \mathrm{KOH}$, and water, and calcined $\left(600{ }^{\circ} \mathrm{C}, 15 \mathrm{~min}\right)$ to obtain a composite. Characterization by XRD confirmed the $\mathrm{MFe}_{2} \mathrm{O}_{4} / \mathrm{CNS}$ structure. The FTIR spectra of the composites showed different band sharpness related to $\mathrm{C}-\mathrm{O}$ and $\mathrm{M}-\mathrm{O}$. A mixture of dried paddy farm soil, composite, BPMC (buthylphenylmethyl carbamate) pesticide solution $(0.25 \%)$, and $\mathrm{H}_{2} \mathrm{O}_{2}$ solution $(0.15 \%)$ was kept under dark conditions for $48 \mathrm{~h}$. The solution above the soil was filtered and measured with a UV-Vis spectrophotometer at $217 \mathrm{~nm}$. Applications without the composite and composite- $\mathrm{H}_{2} \mathrm{O}_{2}$ were also conducted. The results reveal that dark BPMC degradation with the composite was 7.5 times larger than that without the composite, and 2.9 times larger than that without the composite- $\mathrm{H}_{2} \mathrm{O}_{2}$. There were no significantly different FTIR spectra of the soil, soil-BPMC, soil-BPMC- $\mathrm{H}_{2} \mathrm{O}_{2}$, and soil-BPMC- $\mathrm{H}_{2} \mathrm{O}_{2}$ composite and no significantly different $\mathrm{X}$-ray diffractograms between the soil after drying and soil after application for pesticide degradation using the composite.
\end{abstract}

Keywords: $\mathrm{MFe}_{2} \mathrm{O}_{4} / \mathrm{CNS}$ composite; rice husk; hydrothermal-microwave method; pesticide

\section{Introduction}

Pesticides are chemicals used to fight pests and disease vectors in agricultural or domestic settings. They are toxic substances, but their use in agriculture helps improve crop yield. However, pesticides can become biocides, i.e., harming all other life, such as pets, frogs, fish, and plant resistance [1]. Pesticides can also accumulate in both raw and cooked agricultural products [2]. The negative effect of pesticides on humans include cancer, defects, brain damage, genetic mutation, and decrease in immunity. Organochlorine and organophosphate pesticides have high toxicity and long persistence in the soil. While carbamate and pyrethroid are easily degraded, long-term usage can result in accumulation [1].

Pesticide degradation is related to the chemical transformation from a molecule to a simpler and less-toxic form. It can be categorized into two groups, i.e., chemical and biological degradation. Chemical degradation generally occurs in water or atmosphere and follows oxidation, reduction, hydrolysis, or photolysis reactions. Biological degradation generally occurs in soil and living organisms by oxidation, reduction, hydrolysis, or 
conjugation reactions. Oxidation is a reaction between the pesticide and dissolved oxygen in the environment. It can also be achieved by singlet oxygen, ozone, hydrogen peroxide, or other hydroxy radicals [3]. Hydrogen peroxide is a liquid fertilizer additive used to handle fungi and bacteria in plant growth [4]. This substance is used safely in fish pan to increase DO [5]. It means that usage of hydrogen peroxide as oxidator in degradation of pesticide in the soil will not danger the water environment.

Removal of pesticides can be done with activated carbon, which can adsorb pesticide and microbes in the soil and facilitate biological degradation [2]. However, activated carbon has a less surface area than nanocarbons due to its particle size. For example, the activated carbon of empty fruit bunch biomass has a lesser surface area than graphene or CNT from the same biomass [5]. Surface area is an important characteristic for adsorbents due to determining the contact of the surface of the adsorbent and the adsorbate. A small particle size generates a larger surface area of the solid [6]. On the other hand, the nano size of the carbon is needed for easy formation of colloids. This helps farmers to easily spray pesticide together with a liquid fertilizer. Beside potency of nanocarbons as a remediator of the polluted soil, they can also be used to improve soil quality through slow release of the fertilizer by the carbon [7].

Carbon nanomaterials have been synthesized by thermal pyrolysis using a conventional furnace [8], hydrothermal pyrolysis [9,10], microwave [11,12], and sequential hydrothermal-microwave pyrolysis $[13,14]$. The hydrothermal pyrolysis method is characterized by high pressure and low temperature. It is conducted under heating and pressure in the closed vessel. This pressure is generated by vapor pressure. Water is needed in the hydrothermal reaction as a reactant, solvent, or puffing accelerator [15]. This method is good for synthesis of carbon nanomaterials, although it still needs long periods of pyrolysis. For example, xylose and pine were pyrolyzed hydrothermally at a low temperature, i.e., at $180{ }^{\circ} \mathrm{C}$ for $12 \mathrm{~h}$, to obtain CNS, which was of $80 \mathrm{~nm}$ and 50-100 nm, respectively [9]. The other example is synthesis of carbon spheres from pyrolysis of lignin hydrothermally at $270{ }^{\circ} \mathrm{C}$ for $7 \mathrm{~h}$, resulting in carbon particle size of 30-60 $\mathrm{nm}$ [16].

Conventional pyrolysis can perform shorter pyrolysis than hydrothermal pyrolysis but at higher temperatures. For example, the pyrolysis of N. tabacum stems using crucible in a conventional tube furnace under a stream of nitrogen gas at $400{ }^{\circ} \mathrm{C}$ for 2,3 , and $4 \mathrm{~h}$ resulted in nanocarbons size of $54.88,36.80$, and $25.34 \mathrm{~nm}$, respectively [8].

Microwave pyrolysis is faster and needs a shorter time than both conventional thermal and hydrothermal methods. This is because its mechanism of heating effectively starts from the center of the material. Electromagnetic waves penetrate it and interact with molecules in the materials, resulting in a transfer to thermal energy [12]. For example, pyrolysis of rice husk with catalyst of ferrocene, $\mathrm{Fe}\left(\mathrm{C}_{5} \mathrm{H}_{5}\right)_{2}$, using a microwave at $600 \mathrm{~W}$ for $38 \mathrm{~min}$, results in CNS that has tubular and sphere morphology [11].

When combined, the hydrothermal-microwave method sequentially can complete a pyrolysis reaction. Based on FTIR spectra, the sequential hydrothermal-microwave pyrolysis of gelam wood bark resulted in more oxy functional groups than with the microwave [13]. On the other hand, the hydrothermal-microwave pyrolysis of patchouli biomass produced less groups than with the hydrothermal method [14].

Biomass is a term addressing all plants, materials based on plants, and residual materials [17]. Biomass mainly includes lignocellulose, including cellulose, hemicellulose, and lignin of 40-60, 20-40, and 10-25 wt.\%, respectively. All biomasses contain carbon atoms and can be pyrolyzed to produce nanocarbons. Pyrolysis of biomass involves dehydration of moisture and decomposition of lignocellulose [18]. Rice husk is a huge source of biomass in Indonesia, primarily due to high consumption of the grain. Rice husk has been used as a precursor of nanocarbons.

Nanocarbons have been modified using metal oxides for various applications, such as in photocatalysts, electrochemical capacitors, gas sensors, and Li-ion batteries. A composite of a nanocarbon-metal oxide can be prepared using the conventional method or the microwave method [19]. $\mathrm{ZnFe}_{2} \mathrm{O}_{4}$ is a double-layered oxide substance. It is highly 
beneficial as a catalyst due to its double metal cation. This zinc ferrite has a lower bandgap $(1.9 \mathrm{eV})$ than $\mathrm{ZnO}(3.37 \mathrm{eV})$ and was obtained by calcination of $\mathrm{Zn}-\mathrm{Fe}-\mathrm{LDH}$ at $600{ }^{\circ} \mathrm{C}$ [20] and $950{ }^{\circ} \mathrm{C}$ [21]. $\mathrm{Zn}-\mathrm{Fe}-\mathrm{LDH}$ was precipitated from a solution of $\mathrm{Zn}^{2+}$ and $\mathrm{Fe}^{3+}$ salts using $\mathrm{NaOH}$ solution $[20,21]$.

$\mathrm{ZnFe}_{2} \mathrm{O}_{4}$ is type of spinel, i.e., a metal oxide that has the chemical formula of $\mathrm{AB}_{2} \mathrm{O}_{4}$ with $\mathrm{A}^{2+}$ and $\mathrm{B}^{3+}$ metal cations and $\mathrm{O}^{2-}$ anions. Various methods have been applied to synthesize nanospinels, such as ball milling, sol-gel, thermal decomposition, co-precipitation, solvothermal, solution combustion, hydrothermal, and ceramic route techniques. Among these methods, dry thermal decomposition offers the simplest preparation. $\mathrm{MFe}_{2} \mathrm{O}_{4}$ is called ferrospinel and has three kinds of structures, i.e., a normal structure, an inverse structure, and a mixed structure. In the normal structure, M(II) occupy tetrahedral sites and $\mathrm{Fe}(\mathrm{III})$ octahedral sites. In the inverse structure, M(II) occupy octahedral sites, and $\mathrm{Fe}(\mathrm{III})$ occupy tetrahedral and octahedral sites. In the mixed structure, both sites are occupied by $\mathrm{M}(\mathrm{II})$ and $\mathrm{Fe}(\mathrm{III}) . \mathrm{ZnFe}_{2} \mathrm{O}_{4}, \mathrm{NiFe}_{2} \mathrm{O}_{4}$, and $\mathrm{MnFe}_{2} \mathrm{O}_{4}$ are normal, inverse, and mixed structures, respectively. Synthesis of $\mathrm{ZnFe}_{2} \mathrm{O}_{4}$ and $\mathrm{NiFe}_{2} \mathrm{O}_{4}$ with the same synthesis method (coprecipitation) resulted in different surface areas and bandgaps [22]. $\mathrm{ZnFe}_{2} \mathrm{O}_{4}$ and $\mathrm{NiFe}_{2} \mathrm{O}_{4}$ have different crystallite sizes [22,23].

Taking into consideration the above-described aspects, including potency of rice husk as a precursor of nanocarbons, hydrothermal-microwave pyrolysis in the formation of nanocarbons, simplicity of $\mathrm{MFe}_{2} \mathrm{O}_{4} / \mathrm{CNS}$ formation by calcination, and performance of nanocarbon as an adsorbent and $\mathrm{MFe}_{2} \mathrm{O}_{4}$ as a catalyst, the synthesis of $\mathrm{MFe}_{2} \mathrm{O}_{4} / \mathrm{CNS}$ composites was conducted in this research work. Purpose of this research was to study the influence of $\mathrm{M}$ (II) cations on functional groups of composites and their performance in pesticide degradation by oxidation reaction without light (in dark) with the assumption that the reaction was lasted in the depth of soil with no sunlight.

\section{Materials and Methods}

\subsection{Material and Instrumentation}

This research used biomass (rice husk) as a carbon precursor. Some chemicals were used for chemical activation of pyrolysis and as precursor of the composite, i.e., $\mathrm{ZnCl}_{2}$ (Merck)], and precursors of ferrospinel $\left(\mathrm{MFe}_{2} \mathrm{O}_{4}\right)$, including $\mathrm{FeCl}_{3}$ (Merck; Darmstadt, Germany), $\mathrm{KOH}$ (Merck; Darmstadt, Germany), $\mathrm{NiCl}_{6} \cdot 6 \mathrm{H}_{2} \mathrm{O}$ (Merck; Darmstad, Germany), $\mathrm{MnCl}_{2} \cdot 6 \mathrm{H}_{2} \mathrm{O}$ (Merck; Darmstadt, Germany), and distilled water.

Some thermal tools were used, i.e., an oven (Memmert, Büchenbach, Germany) for hydrothermal pyrolysis, microwave (Panasonic, NN-GT35HM, Osaka, Japan), and furnace (Carbolite, Derbyshire, UK). Instruments used for characteriza-tion were FTIR spectrometer (Shimadzu, Kyoto Japan), X-ray diffractometer (PANa-lytical X'PERT PRO, Malvern, UK), and UV-Vis spectrophotometer (FEI Inspect-S50, Hillsboro, OR, USA).

\subsection{Synthesis of $\mathrm{MFe}_{2} \mathrm{O}_{4} / \mathrm{CNS}$ from Rice Husk}

Rice husk (G) biomass (>60 mesh) of $10 \mathrm{~g}, \mathrm{ZnCl}_{2}$ of $0.2 \mathrm{~g}$, and water of $20 \mathrm{~mL}$ were put in an autoclave and pyrolyzed in an oven $\left(6 \mathrm{~h} ; 200{ }^{\circ} \mathrm{C}\right)$, then pyrolyzed further using a microwave $(800 \mathrm{~W} ; 40 \mathrm{~min})$ in a porcelain crucible. The crucible cover was adjusted to leave a little space for gas emission. The microwave pyrolysis was stopped every $10 \mathrm{~min}$ to prevent the broken crucible. The product was unwashed to obtain $\mathrm{ZnO} / \mathrm{CNS}$.

For synthesis of the composite, the carbon product $(1 \mathrm{~g})$ was mixed with $\mathrm{ZnCl}_{2}(0.2 \mathrm{~g})$, $\mathrm{FeCl}_{3}(0.952 \mathrm{~g}), \mathrm{KOH}(1.344 \mathrm{~g})$, and water $(1 \mathrm{~mL})$, and calcined in a closed crucible at $600{ }^{\circ} \mathrm{C}$ for $15 \mathrm{~min}$ to obtain the $\mathrm{ZnFe}_{2} \mathrm{O}_{4} / \mathrm{CNS}$ composite using a conventional furnace. The same procedure was repeated using $\mathrm{NiCl}_{2}$ and $\mathrm{MnCl}_{2}$ as substitution for $\mathrm{ZnCl}_{2}$. G-Zn(Fe), G$\mathrm{Ni}(\mathrm{Fe})$, and G-Mn(Fe) were codes for $\mathrm{ZnFe}_{2} \mathrm{O}_{4} / \mathrm{CNS}, \mathrm{NiFe}_{2} \mathrm{O}_{4} / \mathrm{CNS}$, and $\mathrm{MnFe}_{2} \mathrm{O}_{4} / \mathrm{CNS}$, respectively. The thermal instruments used in the synthesis and placement of the crucible in the microwave and furnace are shown in Figure 1. 


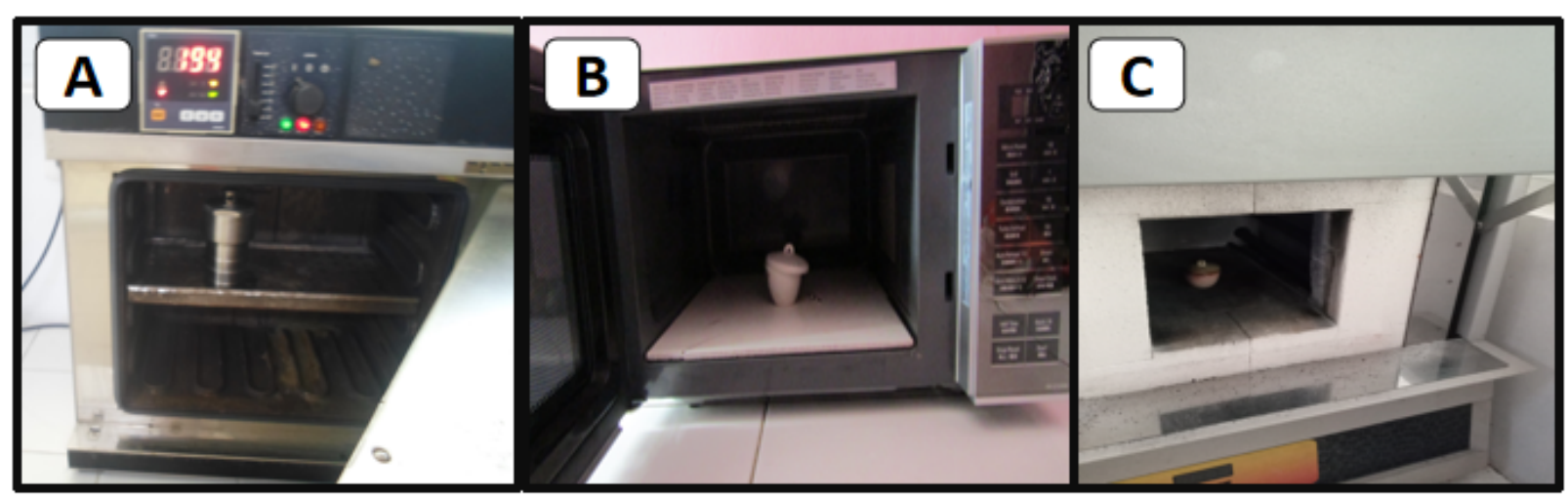

Figure 1. Placement of: (A) Autoclave in the oven, (B) crucible in the microwave, and (C) crucible in the furnace.

\subsection{Characterization}

In this research, characterizations were conducted for biomass, composites, and soil. Biomass was characterized by FTIR spectrometry to identify its functional groups. All synthesized composite products were characterized by FTIR spectrometry and XRD.

The dry soil before contamination by pesticide (TS200), after contamination (BT), after contamination and remediation by $\mathrm{H}_{2} \mathrm{O}_{2}$ (BHT), and after contamination and remediation by $\mathrm{H}_{2} \mathrm{O}_{2}-\mathrm{ZnFe}_{2} \mathrm{O}_{4} / \mathrm{CNS}$ [TG-Zn(Fe)] was characterized by FTIR spectrometry. Only the dry soil before contamination (TS200) and after contamination and remediation by $\mathrm{H}_{2} \mathrm{O}_{2}$ $\mathrm{ZnFe}_{2} \mathrm{O}_{4} / \mathrm{CNS}$ [TG-Zn(Fe)] were characterized by XRD.

\subsection{Application of Composites for Catalytic Dark Degradation}

Pesticide solution (BPMC; $0.25 \%$ ) was prepared by dissolution of concentrated BPMC $(500 \mathrm{~g} / \mathrm{L})$. Paddy soil was dried in an oven at $200{ }^{\circ} \mathrm{C}$ for $1 \mathrm{~h}$ and repeated 5 times. The dry soil $(10 \mathrm{~g})$ was mixed with $25 \mathrm{~mL}$ of BPMC solution $(0.25 \%), 10 \mathrm{~mL}$ of $\mathrm{H}_{2} \mathrm{O}_{2}$ solution $(0.15 \%)$, and kept for $48 \mathrm{~h}$ in a dark place. The solution was then filtered and measured with a UV-Vis spectrophotometer at maximum wavelength of BPMC $( \pm 217 \mathrm{~nm})$. The treatment was repeated three times.

The BPMC solution was marked as B. The sample filtrates and residues were labeled to match with the treatment, including the contaminated soil (BT) and the contaminated and remediated soil by $\mathrm{H}_{2} \mathrm{O}_{2}$ (BHT).

The filtrates of the contaminated and remediated soil by $\mathrm{H}_{2} \mathrm{O}_{2}-\mathrm{MFe}_{2} \mathrm{O}_{4}$ were marked to match with the codes of the composites, i.e., $\mathrm{G}-\mathrm{Zn}(\mathrm{Fe}), \mathrm{G}-\mathrm{Mn}(\mathrm{Fe})$, and $\mathrm{G}-\mathrm{Ni}(\mathrm{Fe})]$. The residues of the filtration for the contaminated and remediated soil by $\mathrm{H}_{2} \mathrm{O}_{2}-\mathrm{MFe}_{2} \mathrm{O}_{4}$ were marked by TG-Zn(Fe), TG-Mn(Fe), and TG-Ni(Fe).

\section{Results and Discussions}

\subsection{Material Transformation}

Carbon nanostructures from the biomass of rice husk was prepared using the hydrothermal-microwave pyrolysis method. There was no more conditioning of carbon to reduce particle size before preparation of the composites; thus, the nanosizes were conditioned by hydrothermal and microwave heating. The composites of $\mathrm{MFe}_{2} \mathrm{O}_{4} / \mathrm{CNS}$ were prepared with conventional heating from a mixture of CNS, salts of metal chloride, and $\mathrm{KOH}$. The change of material from biomass to composites is presented in Figure 2.

Colour conversion from brown to black is a consequence of the pyrolysis reaction, which alternated the chemical structures of lignocellulose to that of carbon material. Reaction mechanisms of the hydrothermal conversion from components of lignocellulose, including lignin, hemicellulose, and cellulose to carbon has been explained in another research work [24]. It is principally related to the formation of aromatics rings as part of graphene layers. The two-step reaction in this research with the proposed stoichiometric reactions is as follows: 
1. Pyrolysis of biomass in the microwave using the $\mathrm{ZnCl}_{2}$ activator produced an intermediate composite:

$$
\mathrm{ZnCl}_{2}+\mathrm{C}_{x} \mathrm{H}_{y} \mathrm{O}_{z} \stackrel{\Delta}{\longrightarrow} \mathrm{ZnO}+\mathrm{xC}+\mathrm{zH}_{2} \mathrm{O}(\mathrm{g})+2 \mathrm{HCl}(\mathrm{g})
$$

2. Calcination of $\mathrm{ZnO} / \mathrm{CNS}, \mathrm{KOH}$, chloride salt, $\mathrm{H}_{2} \mathrm{O}$ :

$$
\begin{aligned}
& \mathrm{ZnO}+\mathrm{xC}+2 \mathrm{KOH}+\mathrm{ZnCl}_{2}+2 \mathrm{FeCl}_{3} \stackrel{\Delta}{\longrightarrow} \mathrm{ZnFe}_{2} \mathrm{O}_{4}+(\mathrm{x}-2) \mathrm{C}+2 \mathrm{KCl}+\mathrm{ZnO}+6 \mathrm{HCl}(\mathrm{g})+\mathrm{CO}_{2}(\mathrm{~g}) \\
& \mathrm{ZnO}+\mathrm{xC}+2 \mathrm{KOH}+2 \mathrm{FeCl}_{3}+\mathrm{MnCl}_{2}+6 \mathrm{H}_{2} \mathrm{O} \underset{\mathrm{H}_{2} \mathrm{O}(\mathrm{g})+2 \mathrm{CO}_{2}(\mathrm{~g})}{\stackrel{\Delta}{\longrightarrow}} \mathrm{MnFe}_{2} \mathrm{O}_{4}+(\mathrm{x}-2) \mathrm{C}+2 \mathrm{KCl}+\mathrm{ZnO}+6 \mathrm{HCl}(\mathrm{g})+ \\
& \mathrm{ZnO}+\mathrm{xC}+2 \mathrm{KOH}+2 \mathrm{FeCl}_{3}+\mathrm{NiCl}_{2}+6 \mathrm{H}_{2} \mathrm{O} \stackrel{\Delta}{\longrightarrow} \mathrm{NiFe}_{2} \mathrm{O}_{4}+(\mathrm{x}-2) \mathrm{C}+2 \mathrm{KCl}+\mathrm{ZnO}+6 \mathrm{HCl}(\mathrm{g})+\mathrm{H}_{2} \mathrm{O} \\
& \text { (g) }+2 \mathrm{CO}_{2}(\mathrm{~g})
\end{aligned}
$$

Identification of the final products, which resulted in calcination, was performed by instrumental characterization.

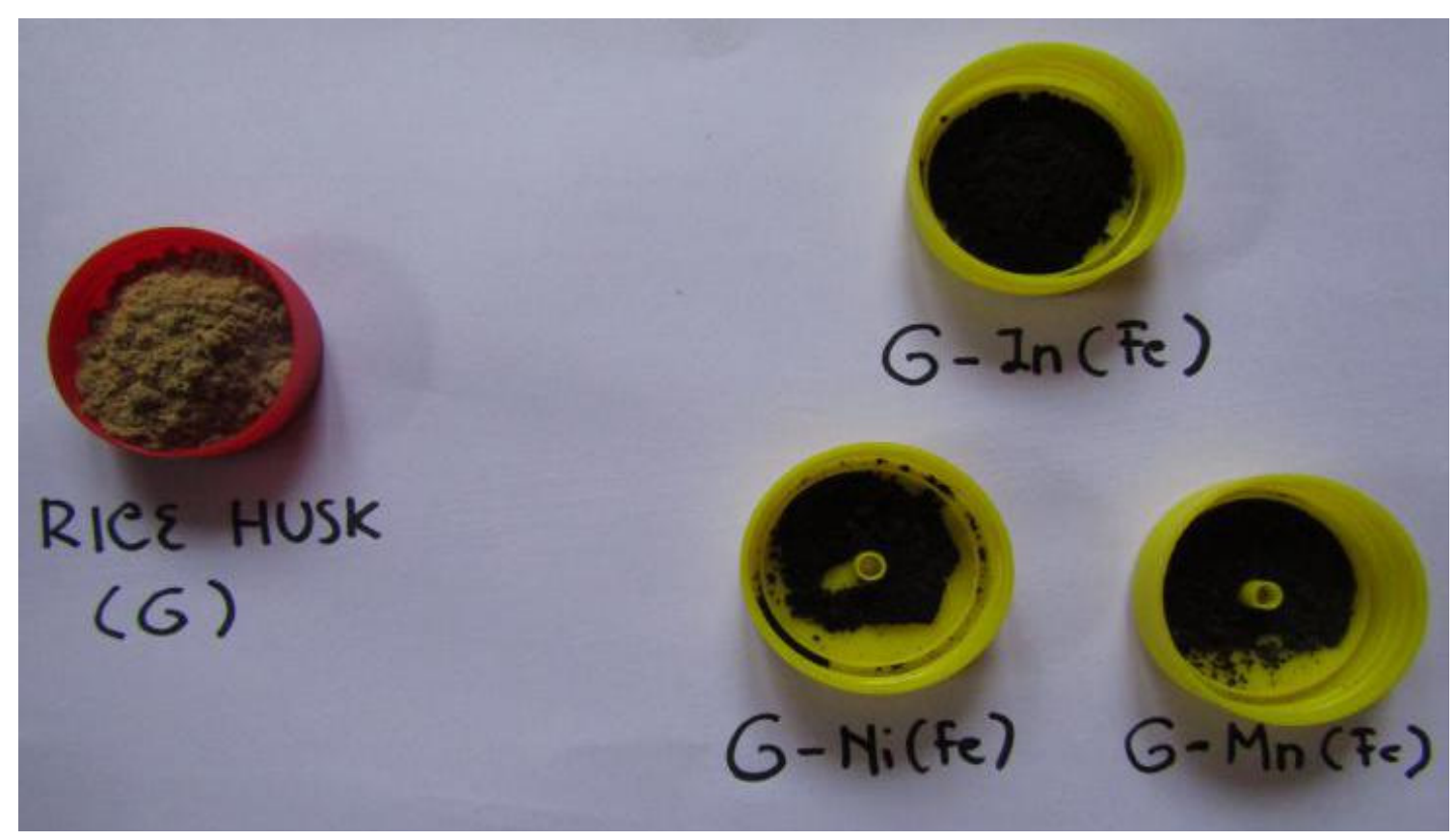

Figure 2. Biomass of rice husk $(G)$ and composite products of $\mathrm{MFe}_{2} \mathrm{O}_{4} / \mathrm{CNS}$.

\subsection{Characterization of Functional Groups}

The rice husk biomass was pyrolyzed using a $\mathrm{ZnCl}_{2}$ activator to produce activated carbon. The hydrothermal method is a pressure-thermal process, while microwave pyrolysis includes electromagnetic penetration, which creates rapid heating of the entire material. Both optimize the nano size of the carbon. Functional groups of the biomass and the composite products were identified based on FTIR spectra (Figure 3). The spectrum of $\mathrm{KCl}$ as impurity of the product could not be identified with FTIR spectrophotometry due to its spectrum emerging in the far infrared region $\left(400-10 \mathrm{~cm}^{-1}\right)$; thus, it was not detected in the center infrared zone, i.e., $4000-400 \mathrm{~cm}^{-1}$ [25]. 


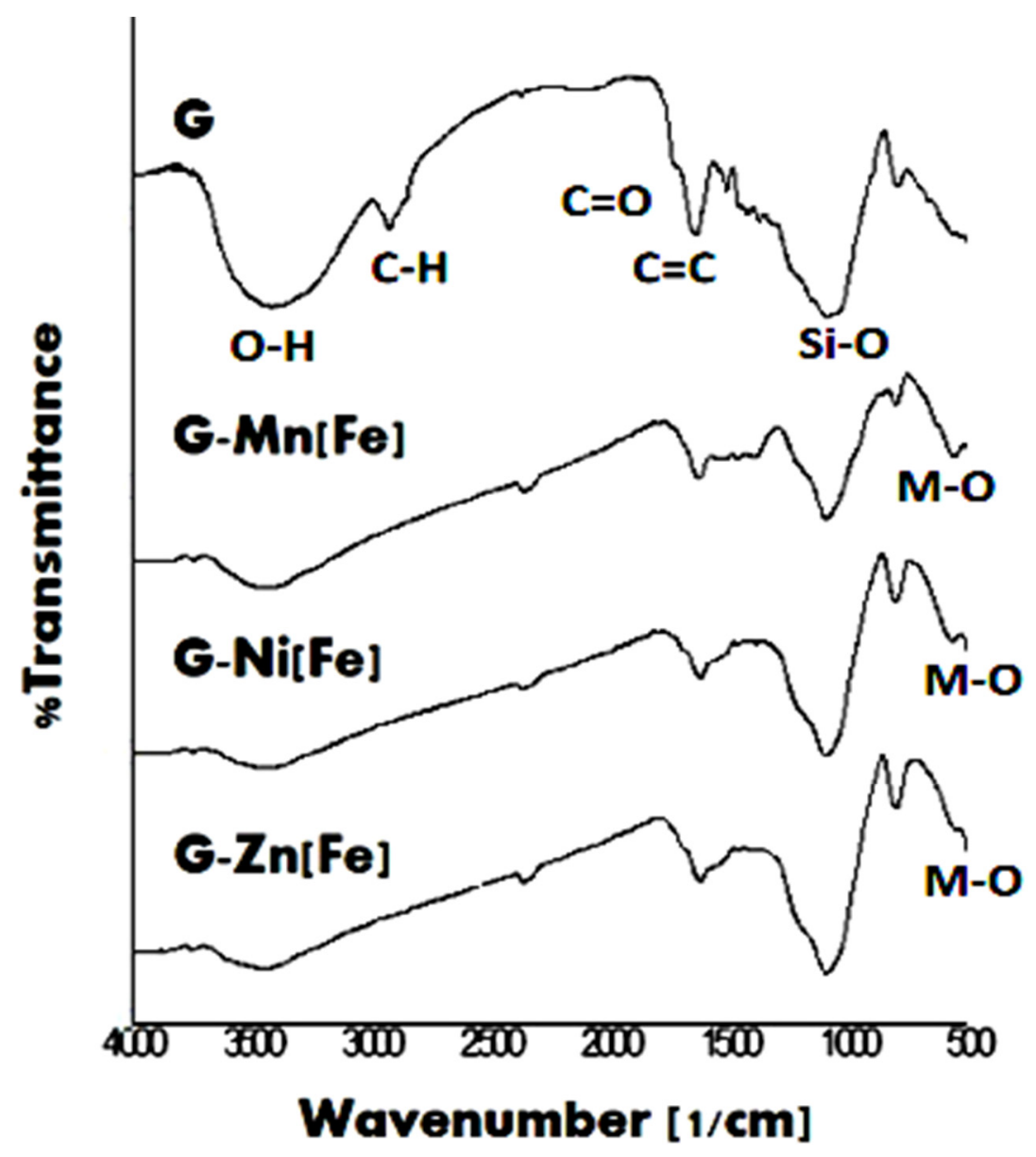

Figure 3. FTIR spectra of rice husk biomass and composites of $\mathrm{MFe}_{2} \mathrm{O}_{4} / \mathrm{CNS}(\mathrm{M}=\mathrm{Zn}, \mathrm{Mn}, \mathrm{Ni})$ in it.

In Figure 3, the spectrum of the biomass shows bands related to functional groups, including -OH at about $3500 \mathrm{~cm}^{-1}$, -aliphatic $\mathrm{C}-\mathrm{H}$ at about $2900 \mathrm{~cm}^{-1}, \mathrm{C}=\mathrm{O}$ at $1700 \mathrm{~cm}^{-1}$, $\mathrm{C}=\mathrm{C}$ at $1600 \mathrm{~cm}^{-1}$, and $\mathrm{C}-\mathrm{H}$ out of plane in the graphene aromatic layer at about $800 \mathrm{~cm}^{-1}$. Based on their chemical structures [26], these groups are matched with the functional groups in general lignocellulose of biomass, i.e., lignin, cellulose, and hemicellulose. All these FTIR spectrum bands were interpreted using the FTIR data of biomass as follows: 3300-4000 (O-H stretching), 2800-3000 (C-H stretching), 1750-1730 (C=O stretching in carbonyl) [27], and the aromatics $-\mathrm{CH}$ at $875-750 \mathrm{~cm}^{-1}$ [28]. The band at about $540 \mathrm{~cm}^{-1}$ is related to $\mathrm{M}-\mathrm{O}$ [29]. It is originally connected to the metal oxide contained in the biomass. The FTIR spectrum of the biomass also indicates the existence of the Si-O band [30] at about $1050 \mathrm{~cm}^{-1}$ and indicates content of inorganic silica or silicate in the biomass.

All composite products show a decrease in the bands, such as $-\mathrm{OH}$, aliphatic $-\mathrm{CH}$, $\mathrm{C}=\mathrm{O}$, compared to the biomass. This indicates that pyrolysis reaction has lasted. In the hydrothermal method, the $\mathrm{ZnCl}_{2}$ activator was used as a chemical activator, improving the pyrolysis reaction. In the modification process, addition of more $\mathrm{ZnCl}_{2}, \mathrm{FeCl}_{3}$, other $\mathrm{MCl}_{2}$, and $\mathrm{KOH}$ into the carbon product resulted in more activation, besides the reaction to form $\mathrm{MFe}_{2} \mathrm{O}_{4}$. Sharper bands of $\mathrm{C}-\mathrm{H}$ out of plan for use of $\mathrm{Ni}^{2+}$ and $\mathrm{Zn}^{2+}$ verified that both cations are stronger activators than $\mathrm{Mn}$ (II); thus, the formation of graphene layers was more effective. These different effects from the chemical activators are related to effective nucleus charge, which is determined by the charge and radius size of the cations. The size of $\mathrm{Zn}^{2+}$ $<\mathrm{Ni}^{2+}<\mathrm{Mn}^{2+}$, indicates that the attraction force of the cation as a Lewis acid toward the Lewis base of the oxygen atom on hydroxide groups increases in the following sequence: $\mathrm{Zn}^{2+}>\mathrm{Ni}^{2+}>\mathrm{Mn}^{2+}$. Those chemical activators have a role as dehydrating agents, which improves pyrolysis reactions and prevents the formation of tar. There was no significant change in $\mathrm{M}-\mathrm{O}$ band after the modification. This may be due to little amounts of metal 
oxide relative to the carbon. The $\mathrm{M}-\mathrm{O}$ bands indicate the existence of metal oxides, as has been predicted in chemical reactions related to both pyrolysis and calcination processes.

\subsection{Characterization of a Composite Crystal Structure by XRD}

The nanocarbon product resulting from the pyrolysis was modified with $\mathrm{MFe}_{2} \mathrm{O}_{4}$ by calcination using conventional heating. The crystal structure of the composite was characterized using XRD at LSUM State University of Malang with a sample code-C1282 from LSUM for G-Zn(Fe). The composite diffractogram was remade by the origin program (presented in Figure 4). The characterized composite is that which supported the highest removal of pesticide by catalytic degradation. This is based on the consideration that $\mathrm{MFe}_{2} \mathrm{O}_{4}$ composites with different $\mathrm{M}$ (II) and from the same biomass (patchouli biomass) gave very similar X-ray diffractogram patterns, indicating the same structure [15].

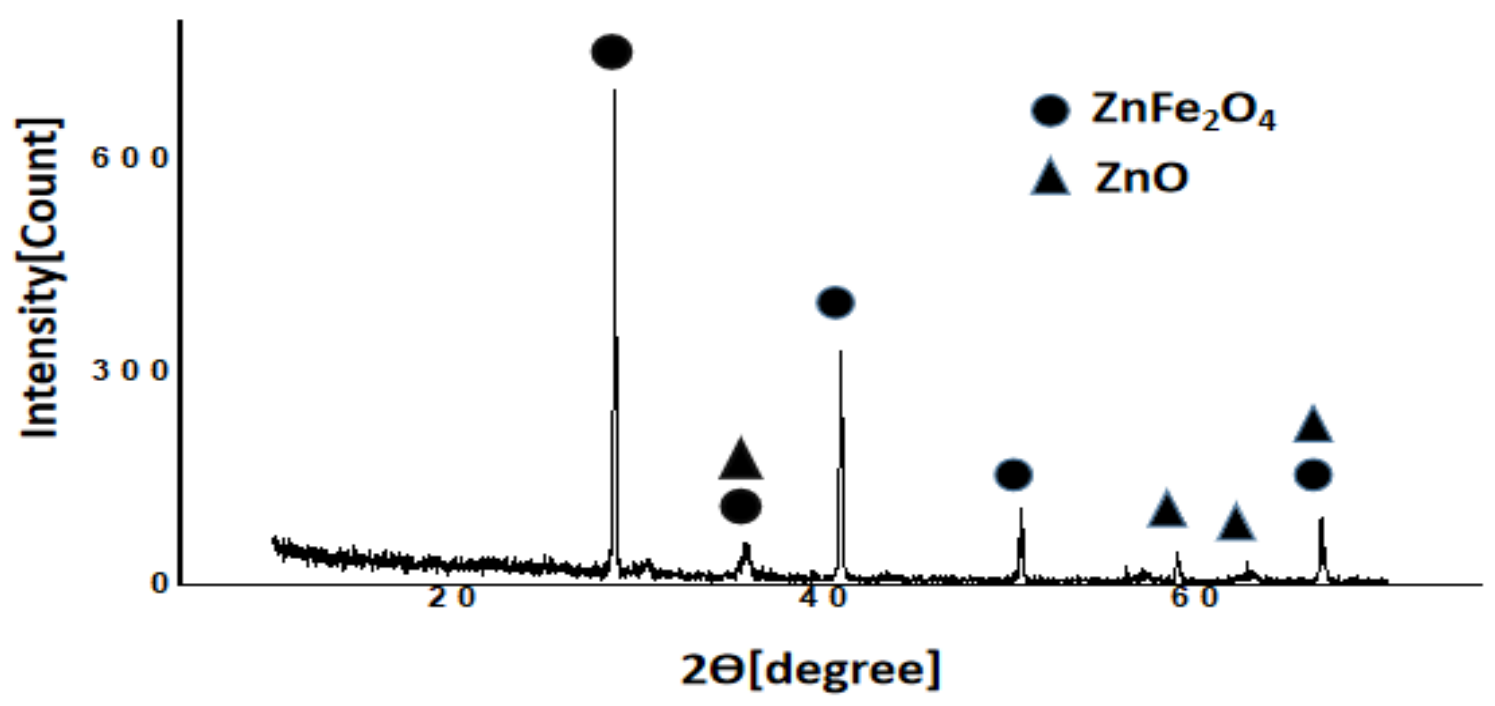

Figure 4. X-ray diffractogram of the $\mathrm{ZnFe}_{2} \mathrm{O}_{4} / \mathrm{CNS}[\mathrm{G}-\mathrm{Zn}(\mathrm{Fe})]$ composite created from rice husk.

The diffractogram in Figure 4 is compared to diffractograms of standard $\mathrm{ZnFe}_{2} \mathrm{O}_{4}$ and $\mathrm{ZnO}$ [20]. $\mathrm{ZnFe}_{2} \mathrm{O}_{4}$ has data of $2 \theta$ (hkl) as follows: 29.9, 35.2, 42.8, 53.2, 56.6, 62.1, and $66.4^{\circ}$ connected to (111), (220), (311), (400), (422), (511), (440), respectively, for the reference code of 01-089-4926. The side product of $\mathrm{ZnO}$ wurtzite has peaks at 36.3, 56.6, 62.9 , and $66.5^{\circ}$, which are related to hkl of (101), (110), (103), and (200), respectively, for the reference code of 01-079-0206. The comparison shows that the composite product contains $\mathrm{ZnFe}_{2} \mathrm{O}_{4}$ and $\mathrm{ZnO}$.

\subsection{Catalytic Dark Degradation Reaction of the Pesticide}

A test for pesticide degradation was conducted by applying heat at $200{ }^{\circ} \mathrm{C}$ for $5 \mathrm{~h}$ to dry soil. This was not only to remove water but also to kill all bacteria in the soil that had the potency to support biodegradation. Generally, soil bacteria grows optimally at $15-35{ }^{\circ} \mathrm{C}$, but some can live to $100{ }^{\circ} \mathrm{C}$; for example, pyrolobus fumarii [31].

The tests were applied without a catalyst composite but with peroxide acid (BHT), without both peroxide acid and composite (BT), and with composite and peroxide acid [TG-Zn(Fe)]. Data of the degradation is listed in Table 1. The degradation reaction was performed in the dark under the assumption that the selected soil depth is not one where the reaction could be caused by sunlight. Thus, in this treatment, it is not about photodegradation, but catalytic dark degradation. The residues and filtrates after degradation test are shown in Figure 5. 
Table 1. Data of pesticide removal and degradation reaction.

\begin{tabular}{ccccccc}
\hline Sample & $\boldsymbol{\lambda}(\mathbf{n m})$ & Abs & \% Removal & \% Degradation & Average & SD \\
\hline B & 216.0 & 2.970 & & & & \\
BT & 219.5 & 2.817 & 5.15 & & & \\
& 219.0 & 2.893 & 2.59 & & & \\
BHT & 217.5 & 2.915 & 1.85 & & & \\
& 216.5 & 2.937 & 1.11 & & & \\
G-Mn(Fe) & 216.0 & 2.542 & 14.41 & 10.54 & & \\
& 216.0 & 2.524 & 15.02 & 11.15 & 10.74 & 0.35 \\
G-Zn(Fe) & 217.5 & 2.542 & 14.41 & 10.54 & & \\
& 217.0 & 2.533 & 14.71 & 10.84 & & \\
& 217.5 & 2.533 & 14.71 & 10.84 & 11.14 & 0.51 \\
G-Ni(Fe) & 217.0 & 2.510 & 15.59 & 11.72 & & \\
& 215.0 & 2542 & 14,41 & 10.54 & & \\
& 215.0 & 2.533 & 14.71 & 10.84 & 10.64 & 0.17 \\
\hline
\end{tabular}

In the treatment without peroxide acid and composite (BT), the decrease in pesticide is caused by adsorption. In this case, the soil plays the role of an adsorbent. There was no degradation by microbia due to the drying process of the soil. Thus, all other data of percent removal for usage of the catalyst was subtracted from the data of BT to remove the role of adsorption by the soil. However, the data for BHT could not be subtracted due to less percent removal than for BT.

Based on the data in Table 1, it is known that the composite $\mathrm{ZnFe}_{2} \mathrm{O}_{4}$ gave the highest data of pesticide removal. This removal [TG- $\mathrm{Zn}(\mathrm{Fe})]$ is 2.9 times larger than that by the soil (BT) and 7.5 times larger than that by soil- $\mathrm{H}_{2} \mathrm{O}_{2}$ (BHT). The removal of pesticides by soil (BT) and soil- $\mathrm{H}_{2} \mathrm{O}_{2}$ (BHT) were probably caused by the adsorption process.

In the BT system, there is no $\mathrm{H}_{2} \mathrm{O}_{2}$ and catalyst; thus, the a radical formation reaction does not take place. There is peroxide acid but no $\mathrm{Fe}(\mathrm{III})$ cation of the $\mathrm{ZnFe}_{2} \mathrm{O}_{4}$ catalyst, resulting in no radical formation as a result of peroxide acid and the cation $\mathrm{Fe}(\mathrm{III})$ reaction. On the other hand, the molecules of peroxide acid can be adsorbed by the soil, causing a decrease in pesticide adsorption by the soil. This is responsible for the lower pesticide removal of BHT than BT.

By considering mineral type in soil, including muscovite, illite, and maghemite (result of XRD characterization), which are rich of hydroxides, $\mathrm{H}_{2} \mathrm{O}_{2}$ molecules can be adsorbed by the soil through hydrogen bonding. BPMC molecules have $\mathrm{C}=\mathrm{O}$ functional groups; thus, these molecules can also be adsorbed by soil with the same chemical interaction. This interaction explains the possibility of a competition of adsorption between BPMC and $\mathrm{H}_{2} \mathrm{O}_{2}$ by the soil-lower adsorption of BPMC by soil in the presence of $\mathrm{H}_{2} \mathrm{O}_{2}$ than without, as shown in Figure 6. Although $\mathrm{H}_{2} \mathrm{O}_{2}$ can be ionized in wet soil, the characteristic of $\mathrm{H}_{2} \mathrm{O}_{2}$ as a weak acid causes it to mostly exist as a molecule.

Based on an analogy toward Fenton reactions [32] and by considering the spontaneity of a $\mathrm{Fe}(\mathrm{III})$ and $\mathrm{H}_{2} \mathrm{O}_{2}$ redox reaction due to positive $\mathrm{E}^{\circ}$, i.e., $0.07 \mathrm{~V}$ [33], the reaction of peroxide acid and $\mathrm{Fe}(\mathrm{III})$ on [TG- $\mathrm{Zn}(\mathrm{Fe})]$ was used as a starting reaction to form radicals. In the redox reaction concept, $\mathrm{E}^{\circ}\left(\mathrm{Fe}^{3+}, \mathrm{Fe}^{2+}\right)=+0.77 \mathrm{~V}$ and $\mathrm{E}^{\circ}\left(\mathrm{O}_{2}, \mathrm{H}_{2} \mathrm{O}_{2}\right)=+0.70 \mathrm{~V}$ [33] The products of $\mathrm{Fe}(\mathrm{III})$ and $\mathrm{H}_{2} \mathrm{O}_{2}$ are $\mathrm{Fe}(\mathrm{II})$ and $\left[\mathrm{HO}_{2}\right]^{-}$radical. By considering both products and elementary reactions in the Fenton reaction [32], three possible reaction lines in degradation of pesticides can be designed (Figure 7).

As seen in chemical equations, $\mathrm{Fe}(\mathrm{III})$ in $\mathrm{MFe}_{2} \mathrm{O}_{4}$ is the cation that reacts with $\mathrm{H}_{2} \mathrm{O}_{2}$ to form radicals. However, based on \% degradation, $\mathrm{M}$ (II) has a different influence on catalytic activity. In a ferrospinel structure, all $\mathrm{Zn}^{2+}$ cations stay in the tetrahedral site and all $\mathrm{Ni}^{2+}$ cations stay in octahedral sites. In the case of $\mathrm{MnFe}_{2} \mathrm{O}_{4}$, half each of the $\mathrm{Mn}^{2+}$ and $\mathrm{Fe}^{3+}$ cations occupy the tetrahedral sites and octahedral sites [22]. In tetrahedral and octahedral sites, each metal cation is surrounded by 4 and 6 oxygen atoms, respectively. The attraction force of Lewis base oxygen atoms toward Lewis acid metal cations in coordination bonding 
has an influence on the attraction force of metal cations toward BPMC. This explains why $\mathrm{ZnFe}_{2} \mathrm{O}_{4}$ had the highest degradation percentage. Both $\mathrm{MnFe}_{2} \mathrm{O}_{4}$ had less degradation percentages than $\mathrm{ZnFe}_{2} \mathrm{O}_{4}$ because only half of the $\mathrm{Mn}^{2+}$ cations occupy the tetrahedral sites. Although half of the $\mathrm{Fe}^{3+}$ cations also stay in the same tetrahedral sites, the ion radius of $\mathrm{Fe}^{3+}$ is smaller in size than that of $\mathrm{Mn}^{2+}$; thus, the attraction force toward oxygen atoms is stronger, and physically, oxygen atoms provide more of a barrier to BPMC in creating chemical interactions.
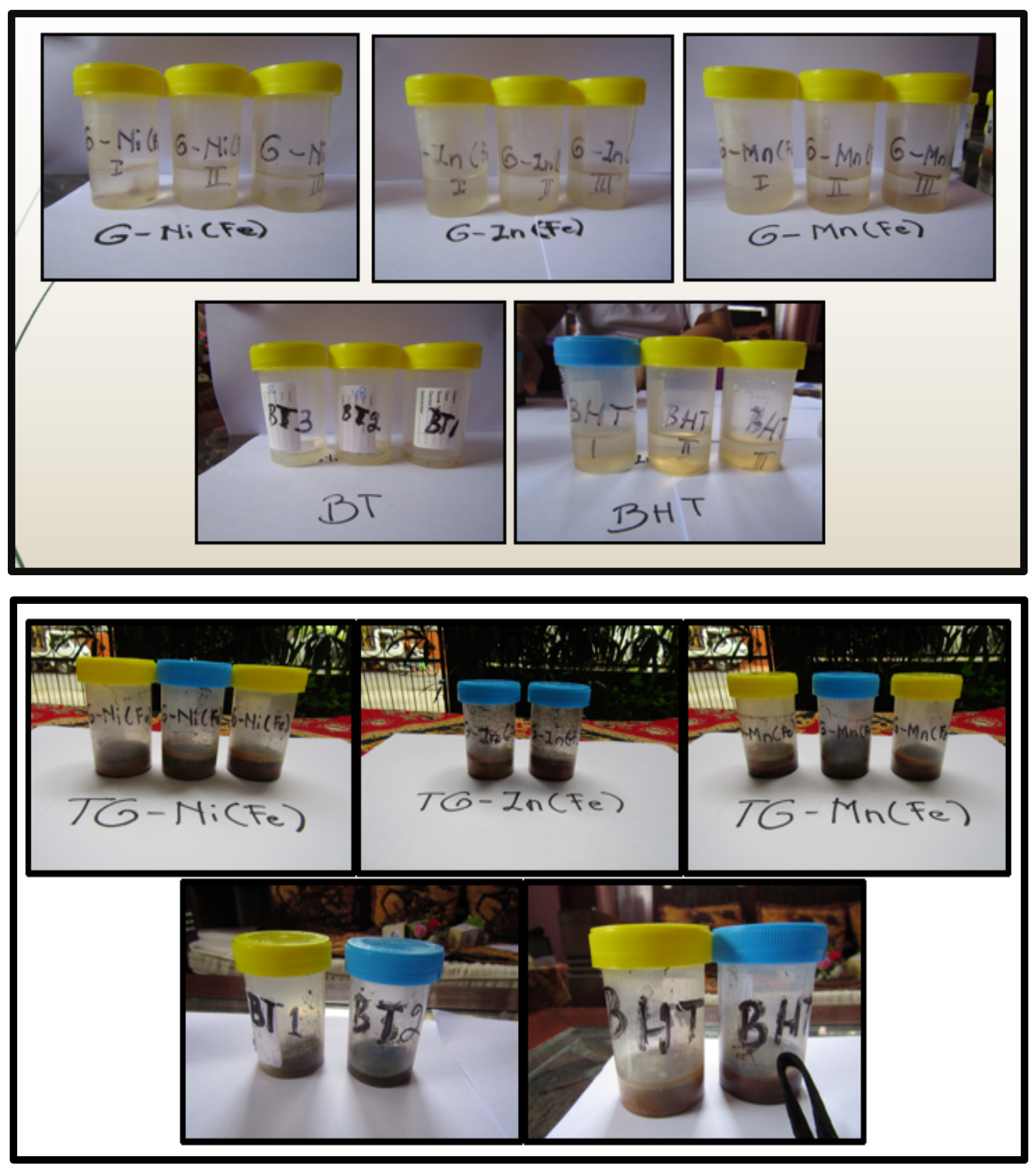

Figure 5. Filtrate and residue of soil after contamination (BT), after contamination and remediation by $\mathrm{H}_{2} \mathrm{O}_{2}(\mathrm{BHT})$, after contamination and remediation by the $\mathrm{H}_{2} \mathrm{O}_{2}$-composite.

In comparison, the oxidation of 4-chlorophenol by $\mathrm{H}_{2} \mathrm{O}_{2}$ was performed using the catalyst of $\mathrm{ZnFe}_{2} \mathrm{O}_{4}$ and $\mathrm{MnFe}_{2} \mathrm{O}_{4}$ without radiation at $70{ }^{\circ} \mathrm{C}$. The usage of $\mathrm{ZnFe}_{2} \mathrm{O}_{4}$ and $\mathrm{MnFe}_{2} \mathrm{O}_{4}$ achieved COD $100 \%$ removal for 120 and $105 \mathrm{~min}$, respectively [34]. The degradation percentage in this research is much lower because the reaction lasted in the soil, as compared to the oxidation reaction of 4-chlorophenol in the solution. The presence of the soil had a negative influence on the reaction of organic oxidation through adsorption 
of organic substance by the porous and polar surface of the soil. A solution provides easier contact between the organic substance, oxidator, and catalyst.

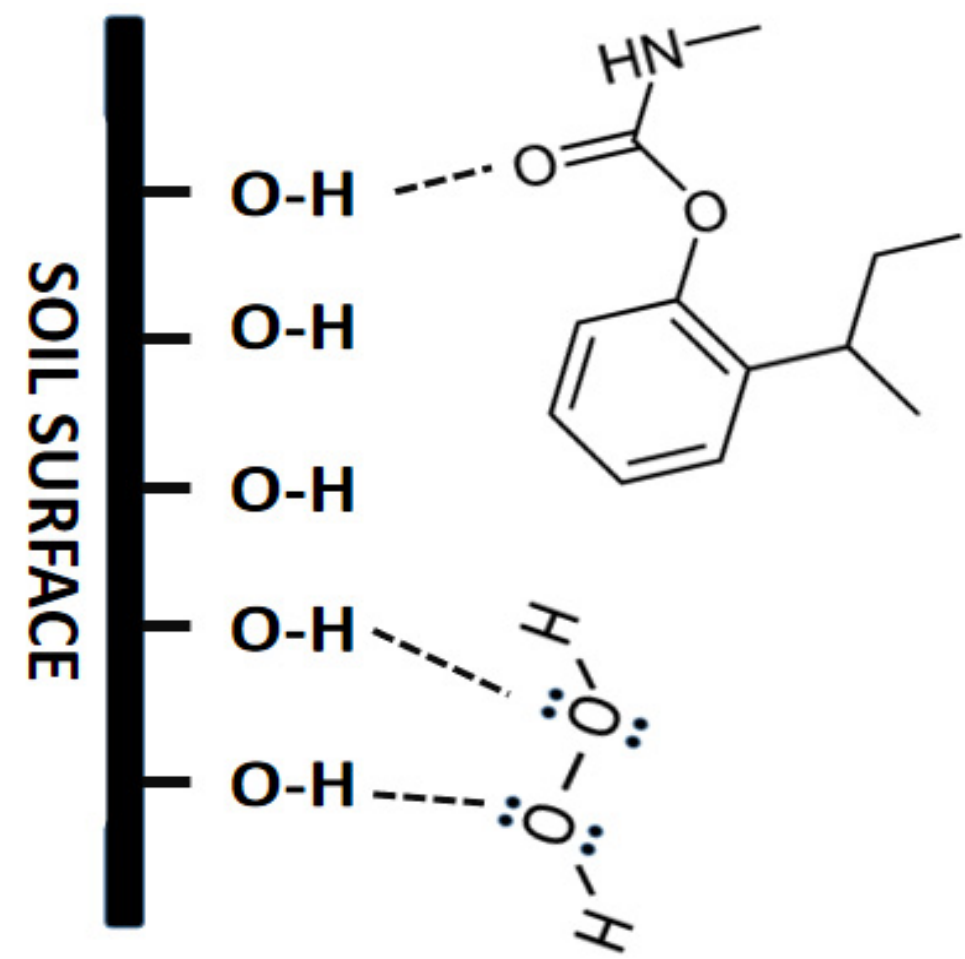

Figure 6. Prediction of the chemical interaction of peroxide acid and BPMC with the surface of the soil.

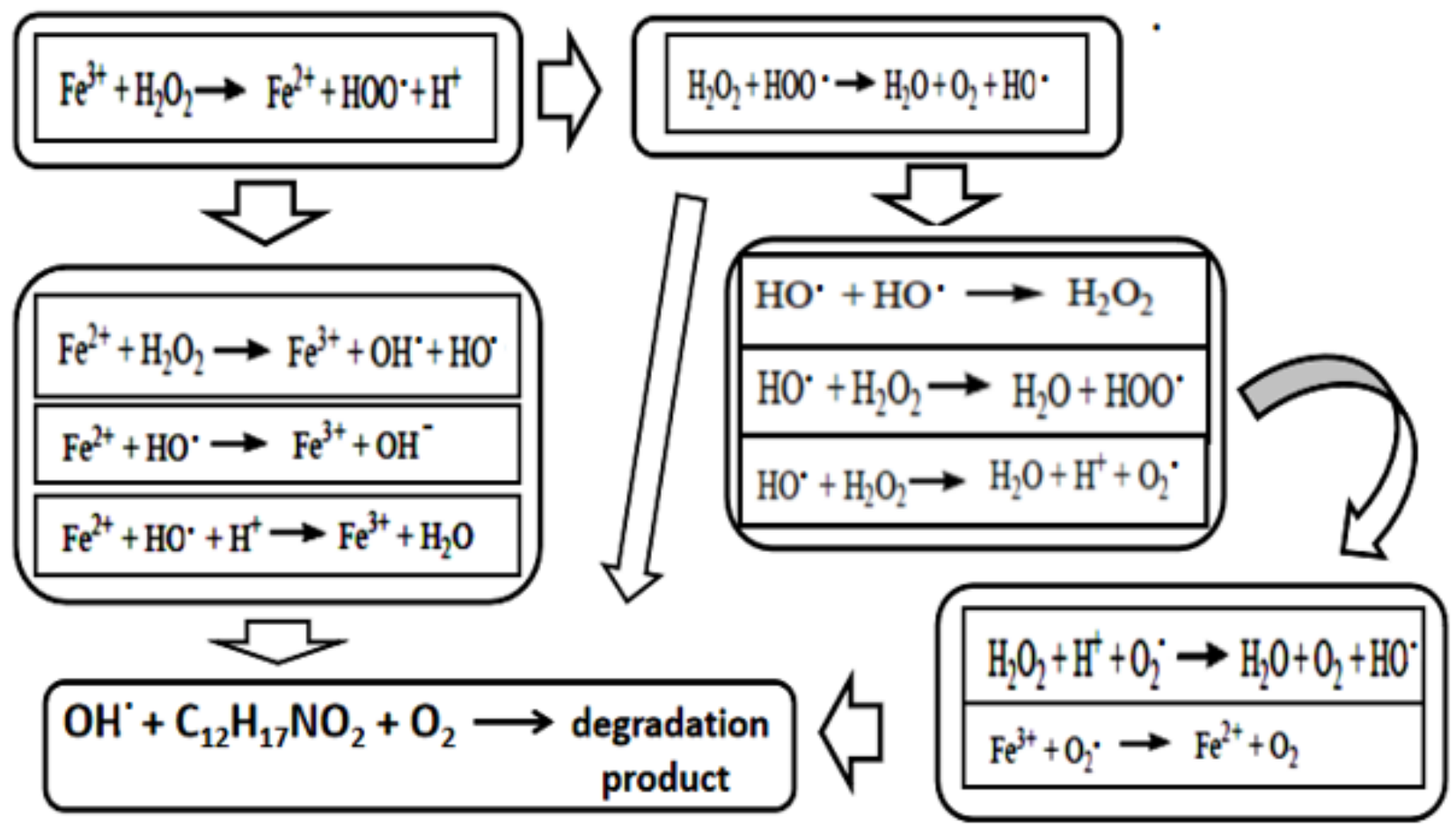

Figure 7. Possible reaction lines in the degradation of pesticides by $\mathrm{H}_{2} \mathrm{O}_{2}$ with a catalyst of $\mathrm{ZnFe}_{2} \mathrm{O}_{4} / \mathrm{CNS}$ based on elementary reactions in Fenton reaction.

The other comparison is between the usage of $\mathrm{NiFe}_{2} \mathrm{O}_{4}$ and $\mathrm{ZnFe}_{2} \mathrm{O}_{4}$ for photocatalytic degradation of methylene blue using the $\mathrm{H}_{2} \mathrm{O}_{2}$ oxidator in the solution; degradation was 
found to be $94 \%$ for both [35]. This higher degradation percentage is due to a radiation treatment along the reaction process, which accelerates the formation of radicals. Again, a solution allows easier contact of the catalyst and the oxidator.

\subsection{Functional Groups of Dry Soil before and after Dark Acylation Degradation of Pesticides}

After the dark degradation test, filtration of the pesticide solution was performed to obtain the residues. Pictures of the dry soil and the residue of BT (dry soil-pesticide), BHT (dry soil-pesticide- $\mathrm{H}_{2} \mathrm{O}_{2}$ ), and TG- $\mathrm{Zn}\left(\mathrm{Fe}\right.$ ) [dry soil-pesticide- $\mathrm{H}_{2} \mathrm{O}_{2}$-composite] are presented in Figure 8. The figures of BT, BHT, and TG- $\mathrm{Zn}(\mathrm{Fe})$ samples in Figure 8 were taken from one of residues in Figure 7 for drying and taking their photograph. The dry soil was dark brown in colour due to the content of hematite and maghemite. The most common color of hematite and maghemite in soil is moderate reddish brown and dark yellowish brown, respectively [36]. The existence of these minerals in soil is studied by X-ray diffraction.

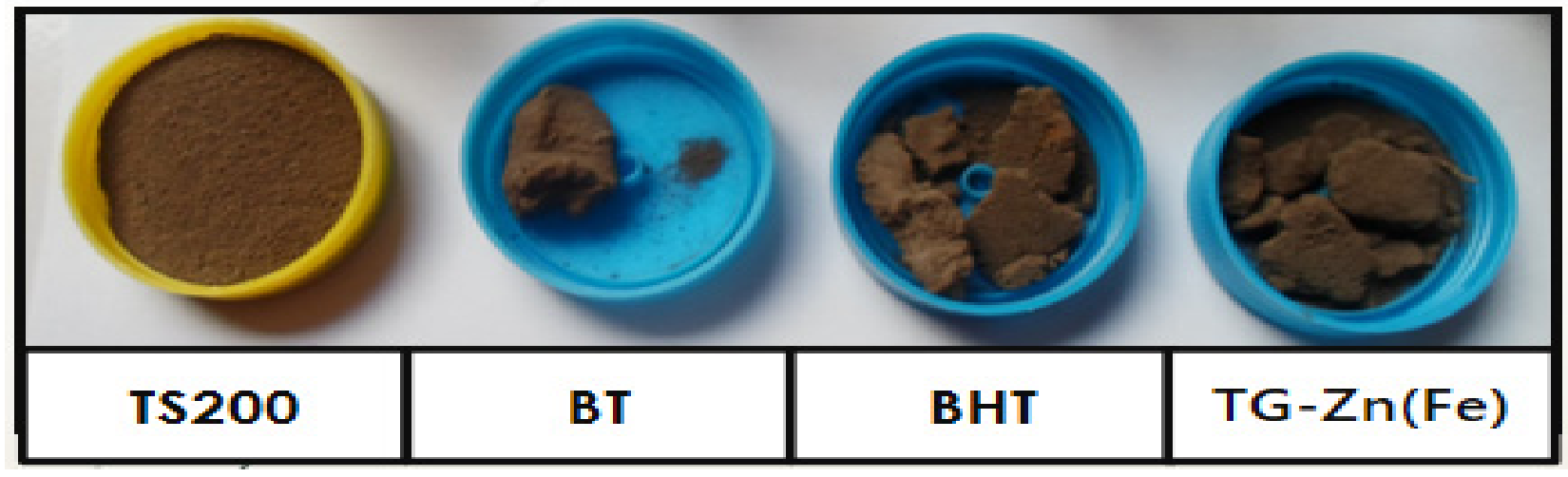

Figure 8. Dry soil before (TS200) and after the dark degradation test: dry soil-BPMC (BT), dry soil-BPMC- $\mathrm{H}_{2} \mathrm{O}_{2}(\mathrm{BHT})$, and dry soil-BPMC- $\mathrm{H}_{2} \mathrm{O}_{2}-\mathrm{MFe}_{2} \mathrm{O}_{4} / \mathrm{CNS}[\mathrm{TG}-\mathrm{Zn}(\mathrm{Fe})]$.

The dry soil and residues were characterized by FTIR spectrometry (Figure 9). The FTIR spectra of both are shown in Figure 9. The spectra show that the dry soil contains a polar group of $-\mathrm{OH}$ at $3500 \mathrm{~cm}^{-1}$ related to the hydrate, stretching $\mathrm{Si}-\mathrm{O}$ at $1000-1100 \mathrm{~cm}^{-1}$, -OH silanol at about $950 \mathrm{~cm}^{-1}$, and both $\mathrm{M}-\mathrm{O}$ and bending Si-O at about $500 \mathrm{~cm}^{-1}$. Sharp bands at $1000-1100 \mathrm{~cm}^{-1}$ indicate silicate and aluminosilicate mineral in the soil. The polar groups of the soil interact with the BPMC molecules in the adsorption process.

There was no significant difference in the soil and the residue spectra. It may be caused by too little amount of the composite, pesticide, and $\mathrm{H}_{2} \mathrm{O}_{2}$ relative to the soil, detectable by FTIR spectrometry.

\subsection{Crystal Structure of Dry Soil before and after Dark Degradation of Pesticides}

Characterization of the soil before [TS200] and after treatment [TG-Zn(Fe)] for the degradation test of pesticides by X-ray diffraction method is presented in Figure 10. The characterization was conducted at LSUM State University Malang with sample codes of C1286 and C1287 from LSUM for TS200 and TG-Zn(Fe), respectively. The diffractograms of both soils show relatively the same points of diffraction angles $(2 \theta)$ for all peaks, which indicate no change in crystal structure due to the degradation test.

The choice of a standard diffractogram for interpretation of the sample diffractograms was based on the mineralogy of paddy soil. There are four types of paddy soils; however, alluvial soil is the most prominent in Indonesia, supported by irrigation and a rainy climate. The types of minerals in alluvial soil include montmorillonite, illite, vermiculite, and kaolinite. [37]. Muscovite $\left[\mathrm{KAl}_{2}\left(\mathrm{AlSi}_{3} \mathrm{O}_{10}\right)(\mathrm{OH})_{2}\right]$, hematite $\left[\alpha-\mathrm{Fe}_{2} \mathrm{O}_{3}\right]$, and quartz $\left[\alpha-\mathrm{SiO}_{2}\right]$ are also considered, as they exist in vulcanic paddy soil [38], and Malang, east Java is near Mount Semeru, which is an active volcano. Maghemite has also been considered for the 
comparison because hematite usually exists in association with maghemite in soil [39]. Maghemite also occurs mainly in tropical and subtropical soils [40].

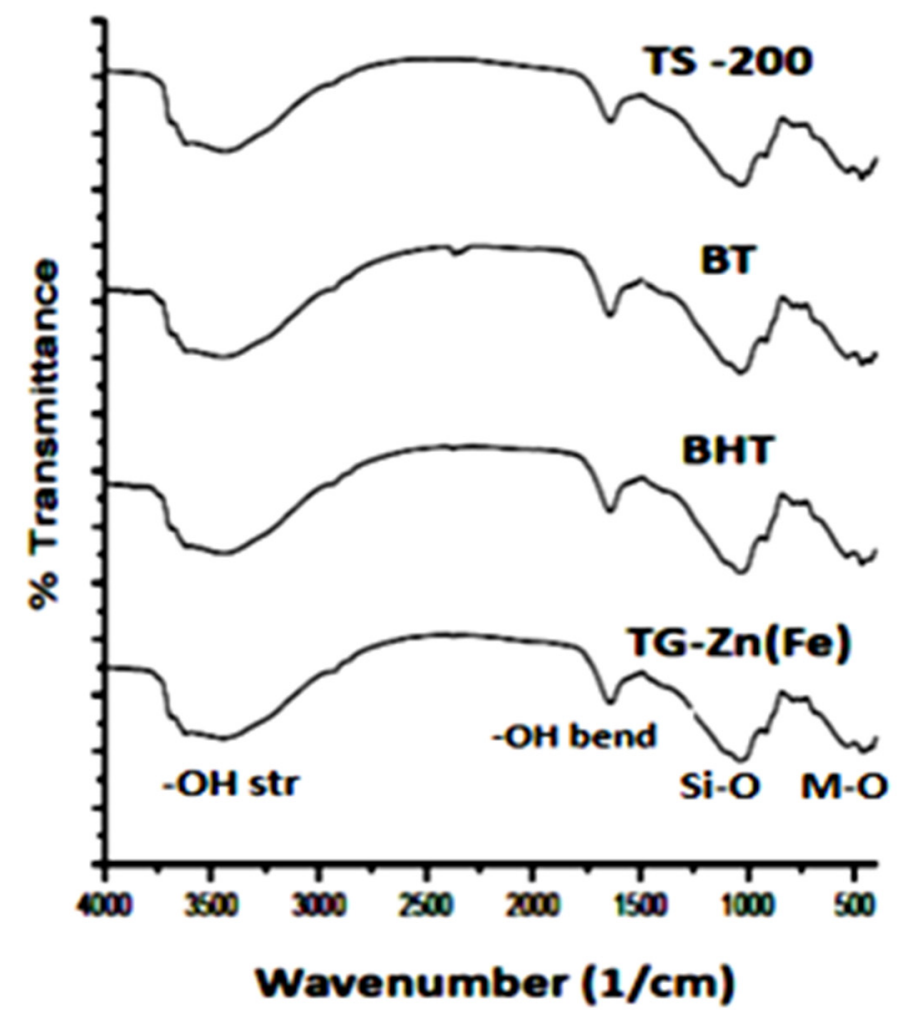

Figure 9. FTIR spectra of dry soil before contamination (TS200), after contamination (BT), after contamination and remediation by $\mathrm{H}_{2} \mathrm{O}_{2}(\mathrm{BHT})$, and after contamination and remediation by $\mathrm{H}_{2} \mathrm{O}$ and $\mathrm{ZnFe}_{2} \mathrm{O}_{4} / \mathrm{CNS}$ (TG-Zn(Fe).

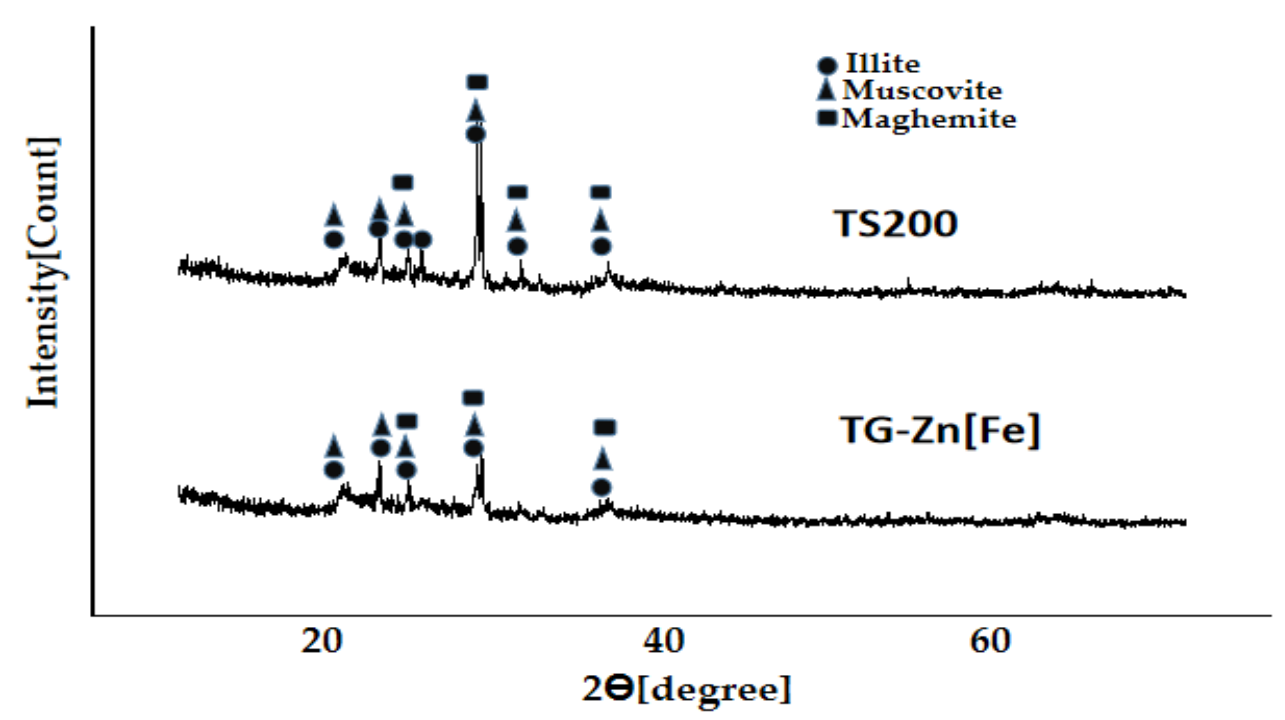

Figure 10. X-ray diffractogram of dry soil (TS200) and the dry soil-BPMC- $\mathrm{H}_{2} \mathrm{O}_{2}-\mathrm{MFe}_{2} \mathrm{O}_{4} / \mathrm{CNS}$ [TG-Zn(Fe)] mixture.

The diffractogram data of dry soil before and after the degradation test was interpreted by a comparison with mineral data in the American Mineralogist Crystal Structure Database (AMCSD). Quick identification of minerals is based on comparison of d-spacing data for three highest peaks of standard minerals to diffractograms of the sample [41]. Intensity of the diffractogram is connected to the amount of the diffracted X-ray. Positions of 2 theta is 
related to Bragg angles and the determined diffraction plans that diffract the X-ray. The highest peak indicates the largest number of same diffraction plans, which build a crystal and diffract the X-ray, so that the three highest peaks of a standard X-ray diffractogram become the main identity of the crystal structure.

The results of the comparison show that three main peaks of illite match with the diffractogram data of the soils. This means that the soils contain the illite mineral. On the other hand, muscovite and maghemite (gamma- $\mathrm{Fe}_{2} \mathrm{O}_{3}$ ) gave two peak (including the highest ones), which match with the data of the sample soil. This means that the soils probably contain those minerals. However, montmorillonite showed one peak match, without including the highest one. Kaolinite and quartz showed two peaks match, without including the highest one. This means that montmorillonite, quartz, and kaolinite content in the soil is questioned.

All soil diffractogram peaks in Figure 8 are named on the basis of the matched standard mineral (AMCSD) in the form of $2 \theta(\mathrm{hkl})$, as follows (the highest peaks are marked with a sign of *:

Illite: 19.77(020)* 21.69(021); 23.32(111); 24.38(-112)*; 29.14(112)*; 30.58(-113); 35.22(200).

Muscovite: 19.89(-111*); 21.60(022); 23.01(71.16); 27.85(114); 28.56(-111); 29.84(025); 31.22(115); 35.02(131)*.

Maghemite: 23.89(210); 26.20(211); 30.35(220); 30.35(220*); 35.75(311)*.

The existence of maghemite is responsible for the presence of $\mathrm{M}-\mathrm{O}$ in the FTIR spectra bands in Figure 3. Illite $\left[\mathrm{K}_{0,65} \mathrm{Al}_{2}\left(\mathrm{Al}_{0,65} \mathrm{Si}_{3,35} \mathrm{O}_{10}\right)(\mathrm{OH})_{2}\right]$ and muscovite belong to a group of clay mineral, i.e., the layered minerals consist of a silicate layer and an aluminate layer. The silicate layers are built by tetrahedron $\mathrm{SiO}_{4}$, held together using oxygen atoms [42]. These silicate layers give Si-O vibrations, which provide a sharp, wide FTIR band at the range of $1000-1050 \mathrm{~cm}^{-1}$.

With regard to intensity, the diffractograms of soil after the degradation test show lower intensity than before. This means that the process of pesticide degradation decreased the crystallinity of the mineral crystals in the soil. Between muscovite, illite, and maghemite, the most influence in the degradation reaction is probably related to maghemite. The maghemite structure contains Fe(III).

\section{Conclusions}

A composite of $\mathrm{MFe}_{2} \mathrm{O}_{4} / \mathrm{CNS}$ was synthesized, characterized, and applied for degradation of the BPMC pesticide. The formation of the composite reduced $-\mathrm{OH}$, aliphatic $-\mathrm{CH}$, and $\mathrm{C}=\mathrm{O}$ content of, but improved aromatic $-\mathrm{C}-\mathrm{H}$, indicating an increase in graphene layer formation. The crystal structure of the composite was a mixture of $\mathrm{ZnFe}_{2} \mathrm{O}_{4} / \mathrm{CNS}$ and $\mathrm{ZnO} / \mathrm{CNS}$. A dark degradation test of the pesticide in wet soil showed that the composite of $\mathrm{ZnFe}_{2} \mathrm{O}_{4} / \mathrm{CNS}$ had the best performance. There was no change in the crystal structure after the test, except for a decrease in crystallinity.

Author Contributions: Conceptualization, T.S.; methodology, T.S., A.N.E., Y.N.Y.; investigation, T.S.; resources, T.S., B.I.; project administration, T.S., S.M., B.S.; funding acquisition, T.S., writing—original draft preparation, T.S.; writing - review and editing, T.S.; supervision, T.S. The main author has responsible fully toward the published version of the manuscript. All authors have read and agreed to the published version of the manuscript.

Funding: This research was funded by HPU 2019 Brawijaya University (DIPA-042.01.0.400919/2019).

Data Availability Statement: All data of the instrumental analysis in this article derived from the original data in attachment of the report of HPU 2019.

Acknowledgments: We thank Brawijaya University for its support, especially the Department of Chemistry for its laboratory facilities.

Conflicts of Interest: The authors declare no conflict of interest. 


\section{References}

1. Ardiwinata, A.N.; dan Nursyamsi, D. Residu Pestisida di Sentra Produksi Padi di Jawa Tengah. J. Pangan 2012, $21,39-58$. [CrossRef]

2. Fitriadi, B.R.; Putri, A.C. Metode-Metode Pengurangan Residu Pestisida pada Hasil Pertanian. J. Rekayasa Kim. Lingkung. 2016, 11, 61-71. [CrossRef]

3. Zacharia, J.T. Identity, Physical and Chemical Properties of Pesticides. In Pesticides in the Modern World—Trends in Pesticides Analysis; Stoytcheva, M., Ed.; InTech: London, UK, 2011. Available online: http:/ /www.intechopen.com/books/pesticidesin-the-modern-world-trends-in-pesticidesanalysis/identiq1ty-physical-and-chemical-properties-of-pesticides (accessed on 1 July 2021).

4. Triyanto, K.B.T. Manfaat Hidrogen Peroksida (H2O2) Bagi Tanaman. Available online: https://kabartani.com/manfaat-hidrogenperoksidah2o2-bagi-tanaman.html (accessed on 18 November 2016).

5. Hendriansyah, R.; Prakoso, T.; Nurdin, I.; Devianto, H.; Widiatmoko, P.; Srimurti, S.; Kusuma, K.R. Nano Carbon Materials from Palm Oil Wastes for Supercapacitor Applications. In Proceedings of the 4th International Conference on Electric Vehicular Technology (ICEVT), Bali, Indonesia, 2-5 October 2017; pp. 13-18. [CrossRef]

6. Lowell, S.; Shields, J.E. Powder Surface Area and Porosity, 2nd ed.; Chapman and Hall Ltd.: New York, NY, USA, $2004 ;$ p. 1.

7. Zaytseva, O.; Neumann, G. Carbon Nanomaterials: Production, Impact on Plant Development, Agriculturaland Environmental Applications. Chem. Biol. Technol. Agric. 2016, 3, 1-26. [CrossRef]

8. Musuna-Garwe, C.C.; Mukaratirwa-Muchanyereyi, N.; Mupa, M.; Mahamadi, C.; Mujuru, M. Preparation and characterizationof nanocarbons from Nicotiana tabacum stems. Mater. Sci. 2018, 5, 1242-1254. [CrossRef]

9. Yan, Q.; Li, R.; Toghiani, H.; Cai, Z.; Zhang, J. Synthesis and Characterization of Carbon Nanospheres Obtained by Hydrothermal Carbonization of Wood-derived and Other Saccharides. Trends Renew. Energy 2015, 1, 119-128. [CrossRef]

10. Haryadi, H.; Purnama, M.R.W.; Wibowo, A. C Dots Derived from Waste of Biomass and Their Photocatalytic Activities. Indones. J. Chem. 2018, 18, 594-599. [CrossRef]

11. Asnawi, M.; Azhari, S.; Hamidon, M.N.; Ismail, I.; Helina, I. Synthesis of Carbon Nanomaterials from Rice Husk via Microwave Oven. J. Nanomater. 2018, 2018, 1-5. [CrossRef]

12. Kure, N.; Hamidon, M.N.; Azhari, S.; Mamat, N.S.; Yusoff, H.M.; Isa, B.M.; Yunusa, Z. Simple Microwave-Assisted Synthesis of Carbon Nanotubes Using Polyethylene as Carbon Precursor. Hindawi J. Nanomater. 2017, 2017, 1-4. [CrossRef]

13. Syarif, N.; Prasagi, M. Preparation of Carbon Nanosheets from Gelam Wood Bark and Its Electrochemical Study. Carbon Sci. Tech. 2016, 8, 5-42. Available online: https://www.researchgate.net/publication/313421521_Preparation_of_carbon_nanosheets_ from_Gelam_wood_bark_and_its_electrochemical_study (accessed on 1 July 2021).

14. Setianingsih, T.; Mutrofin, S. Sintesis Karbon Nanomaterial dari Limbah Biomassa yang Dimodifikasi $\mathrm{MFe}_{2} \mathrm{O}_{4} \mathrm{Secara}_{\mathrm{G}} \mathrm{Green}$ Technologi Sebagai Campuran Pupuk Cair Untuk Remediator Tanah Sawah dan Saluran Irigasi Tercemar Pesticida. In Laporan Akhir HPU; Universitas Brawijaya: Malang, Indonesia, 2019.

15. Yang, G.; Park, S.J. Conventional and Microwave Hydrothermal Synthesis and Application of Functional Materials: A Review. Materials 2019, 12, 1177. [CrossRef]

16. Mao, H.; Chen, X.; Huang, R.; Chen, M.; Yang, R.; Lan, P.; Zhou, M.; Zhang, F.; Yang, Y.; Zhou, X. Fast preparation of carbon spheres from enzymatic hydrolysis lignin: Effects of hydrothermal carbonization conditions. Sci. Rep. 2018, 8, 1-10. [CrossRef]

17. Ayeni, A.O.; Adeeyo, O.A.; Oresegun, O.M.; Oladimeji, T.E. Compositional Analysis of Lignocellulosic Materials: Evaluation of an Economically Viable Method Suitable for Woody and Non-Woody Biomass. Am. J. Eng. Res. 2015, 4, 14-19. Available online: http:/ / eprints.covenantuniversity.edu.ng/5715/1/AJER_Paper_2015\%5B1\%5D.pdf (accessed on 1 July 2021).

18. Yang, H.; Yan, R.; Chen, H.; Lee, D.H.; Zheng, C. Characteristics of Hemicellulose, Cellulose, and Lignin Pyrolysis. Fuel 2007, 86, 1781-1788. [CrossRef]

19. Motshekga, S.C.; Pillai, S.K.; Ray, S.S.; Jalama, K.; Krause, R.W.M. Review Article Recent Trend Microwave-Assisted Synthesis of Metal Oxide Nanoparticles Supported on Carbon Nanotubes and Their Applications. Hindawi Publ. Corp. J. Nanomater. 2012, 2012, 1-15. [CrossRef]

20. Ahmed, A.A.A.; Talib, Z.A.; Hussein, M.Z.; Flaifel, M.H.; Al-Hada, N.M. Influence of Zn/Fe Molar Ratio on Optical and Magnetic Properties of $\mathrm{ZnO}$ and $\mathrm{ZnFe}_{2} \mathrm{O}_{4}$ Nanocrystal as Calcined Products of Layered Double Hydroxides. J. Spectrosc. 2014, $2014,1-6$. [CrossRef]

21. Hongo, T.; Iemura, T.; Yamazaki, A. Adsorption ability for several of Zn-Fe layere double harmful oxide anions and thermal behavior of Zn-Fe double layer hydroxide. J. Ceram. Soc. Jpn. 2008, 116, 192-197. [CrossRef]

22. Kirankumar, V.S.; Sumathi, S. A Review on Photodegradation of Organic Pollutants Using Spinel Oxide. Mater. Today Chem. 2020 18, 1-15. [CrossRef]

23. Jeseentharani, V.; George, M.; Jeyaraj, B.; Dayalan, A.; Nagaraja, K.S. Synthesis of Metal Ferrite ( $\mathrm{MFe}{ }_{2} \mathrm{O}_{4}, \mathrm{M}=\mathrm{Co}, \mathrm{Cu}, \mathrm{Mg}$, Ni, $\mathrm{Zn}$ ) Nanoparticles as Humidity Sensor Materials. J. Exp. Nanosci. 2013, 8, 358-370. [CrossRef]

24. Liu, W.J.; Jiang, H.; Yu, H.Q. Development of Biochar based Functional Materials: Toward a Sustainable Platform Carbon Material. Chem. Rev. 2015, 115, 12251-12285. [CrossRef]

25. Setianingsih, T.; dan Prananto, Y.P. Spektroskopi Inframerah Untuk Material Anorganik; UB Press: Malang, Indonesia, 2020; pp. 82-90.

26. Fu, L.; McCallum, S.A.; Miao, J.; Hart, C.; Tudryn, G.J.; Zhang, F.; Linhardt, R.J. Rapid and Accurate Determination of the Lignin Content of Lignocellulosic Biomass by Solid-State NMR. Fuel 2015, 14, 39-45. [CrossRef] 
27. Ahmad, Z.S.; Munaim, M.S.A.; Said, F.M. Characterization of Meranti Wood Sawdust and Removal of Lignin Content Using Pre-Treatment Process; The National Conference for Postgraduate Research, Universiti Malaysia Pahang: Pahang, Malaysia, 2016. Available online: https: / / www.semanticscholar.org/paper/Characterization-of-Meranti-wood-Sawdust-and-of-Zuriana-Sakinah/00f0 d87ff62e51e56e106f6901cd6870de02c69d (accessed on 1 July 2021).

28. Adewumi, G.A.; Revaprasadu, N.; Eloka-Eboka, A.C.; Inambao, F.L.; CharlesGervas, C. A Facile Low-cost Synthesis of Carbon Nanosphere from Coconut Fibre. In Proceedings of the World Congress on Engineering and Computer Science 2017 Vol II WCECS 2017, San Francisco, CA, USA, 25-27 October 2017; pp. 1-6. Available online: https://www.semanticscholar.org/paper/A-FacileLow-cost-Synthesis-of-Carbon-Nanosphere-Adewumi-Revaprasadu/bfca1a.3ece706aaf75e505a8c0da7de782e6e393 (accessed on 1 July 2021).

29. Lemos de Peres, M.; Delucis, R.D.A.; Amico, S.C.; Gatto, D.A. Zinc Oxide Nanoparticles from Microwave-assisted Solvothermal Process: Photocatalytic Performance and Use for Wood Protection against Xylophagous Fungus. Nanomater. Nanotechnol. 2019, 9 , 1-8. [CrossRef]

30. Hu, P.; Yang, H.; Ouyang, J. Synthesis and Characterization of Sb-SnO 2 /Kaolinites Nanoparticles. Appl. Clay Sci. 2012, 55, 151-157. [CrossRef]

31. Utomo, M.; Sabrina, M.T.; Sudarsono; Lumbanraja, J.; Rusman, B. Ilmu Tanah Dasar-Dasar dan Pengelolaan. Penerbit Kencana, Jakarta; Kencana: Badung, Indonesia, 2016. Available online: https://books.google.co.id/books?id=i1e-DwAAQBAJ\&pg=PA432\&dq= mineral+dalam+tanah+sawah\&hl=en\&sa=X\&ved=2ahUKEwihgK60wZ3uAhWFSH0KHdANChMQ6AEwAHoECAUQAg\# $\mathrm{v}=$ onepage\& $\mathrm{q}=$ mineral\%20dalam\%20tanah\%20sawah\&f=false (accessed on 1 July 2021).

32. Liu, X.; Sang, Y.; Yin, H.; Lin, A.; Guo, Z.; Zhen, L. Progress in the Mechanism and Kinetics of Fenton Reaction. MOJ Ecol. Environ. Sci. 2018, 3, 11-15. [CrossRef]

33. Atkins, P.; Overton, T.; Rourke, J.; Weller, M.; Armstrong, F. Inorganic Chemistry; W. H. Freeman: New York, NY, USA, 2009; pp. 153-164. Available online: http:/ / library.lol/main/647569FC3F0706DD00FE25C437BA0A39 (accessed on 1 July 2021).

34. Kurian, M.; Nair, D.S. Manganese Zinc Ferrite Nanoparticles as Efficient Catalysts for Wet Peroxide Oxidation of Organic Aqueous Wastes. J. Chem. Sci. 2015, 127, 537-546. [CrossRef]

35. Gupta, N.K.; Ghaffari, Y.; Kim, S.; Bae, J.; Kim, K.S.; Saifuddin, M. Photocatalytic Degradation of Organic Pollutants Over MFe ${ }_{2} \mathrm{O}_{4}$ $(\mathrm{M}=\mathrm{Co}, \mathrm{Ni}, \mathrm{Cu}, \mathrm{Zn})$ Nanoparticles at Neutral pH. Sci. Rep. 2020, 10, 1-11. [CrossRef]

36. Scheinost, A.C.; Schwertmann, U. Division S-9-Soil Mineralogy: Color Identification of Iron Oxides and Hydroxysulfates: Use and Limitations. Soil Sci. Soc. Am. J. 1999, 63, 1463-1471. [CrossRef]

37. Prasetyo, B.H.; dan Setyorini, D. Karakteristik Tanah Sawah dari Endapan Aluvial dan Pengelolaannya. J. Sumberd. Lahan 2008, 2, 1-14. Available online: https:/ / media.neliti.com/media/publications/132791-ID-none.pdf (accessed on 1 July 2021).

38. Ahmad, A.; Lopulisa, C.; Imran, A.M.; Baja, S. Mineral Tanah Sebagai Indikator Stabilitas Tanah Pada Daerah Berlereng: Studi Kasus Tombolopao Kabupaten Gowa. J. Ecosolum 2018, 7, 33-37. [CrossRef]

39. Taylor, R.M.; Schwertmann, U. Maghemite in Soils and Its Origin II. Maghemite Syntheses at Ambient Temperature and pH 7. Clay Miner. 1974, 10, 299-310. Available online: http: / / iteseerx.ist.psu.edu/viewdoc/download?doi=10.1.1.619.8244\&rep=rep1 \&type $=$ pdf (accessed on 1 July 2021). [CrossRef]

40. Poggere, G.C.; Inda, A.V.; Barrón, V.; Kämpf, N.; de Brito, A.D.B.; Barbosa, J.Z.; Curi, N. Maghemite Quantification and Magnetic Signature of Brazilian Soils with Contrasting Parent Materials. Appl. Clay Sci. 2018, 161, 385-394. [CrossRef]

41. Setianingsih, T.; Sutarno, D. Prinsip Dasar dan Aplikasi Metode Difraksi Sinar-X untuk Karakterisasi Material; UB Press: Malang, Indonesia, 2018.

42. Barton, C.D.; Karathanasis, A.D. Clay Minerals: Encyclopedia of Soil Science; Marcel Dekker, Inc.: New York, NY, USA, 2002; pp. 187-192. Available online: https://www.srs.fs.usda.gov/pubs/ja/ja_barton002.pdf (accessed on 1 July 2021). 